\section{Optimum Potassium Concentrations in Recirculating Subirrigation for Selected Greenhouse Crops}

\author{
Trisha Blessington Haley ${ }^{1}$ and David Wm. Reed $^{2}$ \\ Department of Horticultural Sciences, Texas A\&M University, College Station, \\ TX 77843-2133 \\ Additional index words. ebb and flow irrigation, flood and drain irrigation, Catharanthus \\ roseus, Impatiens hawkeri, Petunia $\times$ hybrida, zero runoff, zero leach
}

\begin{abstract}
Two experiments were conducted to investigate the effect of $\mathrm{K}$ fertilizer rates on growth of New Guinea impatiens (Impatiens Hawkeri Bull.), vinca (Catharanthus roseus (L.) G. Don) and petunia (Petunia $\times$ hybrida Hort. Vilm.-Andr.) in a recirculating subirrigation system. Based on a variety of growth parameters, a broad range of $K$ concentrations allowed maximum growth, notably 1 to $6 \mathrm{mM}$ for New Guinea impatiens 'Ovation Salmon Pink Swirl', 2 mm for New Guinea impatiens 'Cameo' and 'Illusion', 2 to $8 \mathrm{~mm}$ for vinca 'Pacifica Apricot', and 2 to $16 \mathrm{~mm}$ for petunia 'Trailing Wave Misty Lilac'. Thus, the lowest concentration that allowed maximum growth was 1 to $2 \mathrm{~mm} \mathrm{~K}$. A third experiment compared the optimum $K$ concentration and $K$ balance of vinca grown with recirculating subirrigation versus top-watering. Based on a variety of growth parameters of vinca 'Pacifica Red', the lowest concentration that allowed maximum growth was $2 \mathrm{~mm} K$ with recirculating subirrigation and $4 \mathrm{~mm} K$ with top-watering. The $\mathrm{K}$ balance demonstrated that subirrigated plants were twice as efficient in $\mathrm{K}$ use compared to the top-watered plants. Leachate loss was the major contributor to inefficiency in top-watered plants. Electrical conductivity (EC) of the growing medium remained below the recommended level of $1.2 \mathrm{dS} \cdot \mathrm{m}^{-1}$ in both irrigation methods at $\mathrm{K}$ concentrations of $16 \mathrm{~mm}$ and below in the bottom layer and $8 \mathrm{~mm}$ and below in the middle layer. In the top layer of the growing medium, $\mathrm{EC}$ was above the recommended level at all $K$ concentrations tested in subirrigation at all concentrations, and in top-watering at $16 \mathrm{~mm}$ and above.
\end{abstract}

The public is becoming more concerned with water quality and water conservation, and it is likely that there will be more regulations concerning watermanagement (Skimina, 1996). It is of increasing importance to recognize the need to modify greenhouse production practices due to environmental concerns, cost efficiency, and possible increased governmental regulations (Skimina, 1996; Todd and Reed, 1998). Strategies for optimum plant nutrition with minimum fertilizer usage and environmental contamination are needed.

Zero-leach systems have the potential to reduce runoff of water and fertilizers when growing greenhouse plants (Reed, 1996). Recirculating subirrigation is the most commonly used zero-leach system, and has the additional benefits of less foliar disease, decreased labor, water savings, and a cleaner environment (Elliott, 1992; Fischer, 2000, Yelanich and Biernbaum, 1993). In Europe, recirculating subirrigation has been used for many years to help

Received for publication 23 June 2003. Accepted for publication 11 Feb. 2004. We thank Oglevee LTD and Colorspot for providing plant material, Sun Gro Horticulture for providing growing media, and grant support from the Texas Ornamental Enhancement Program and The Fred C. Gloeckner Foundation, Inc. Use of trade names does not imply endorsement of products named or criticism of similar products not mentioned. Part of Master of Science thesis of T. Blessington Haley.

${ }^{1}$ Graduate student.

${ }^{2}$ Professor. To whom reprint requests should be sent; e-maildwreed@tamu.edu. solve problems with traditional greenhouse irrigation methods (Molitor, 1990). However, the U.S. has not adopted zero leach or recirculating subirrigation as extensively. One contributing factor is that there is little information available to growers about subirrigation (James and van Iersel, 2001).

Research on fertilizer rates for greenhouse plants grown in recirculating subirrigation is limited. Most studies demonstrate that fertilizer concentration in subirrigation can be reduced to $50 \%$ of the rate that is recommended for top watering (Fischer, 2000). Kent and Reed subirrigation and found Impatiens $\times$ hawkeri Bull. 'Barbados' growth was optimal at $8 \mathrm{~mm}$ $\mathrm{N}$ and Spathiphyllum Schott. 'Petite' at $10 \mathrm{~mm}$ $\mathrm{N}$, based upon shoot dry weight. Whipker et al. (1999) focused on N nutrition of two different varieties of Impatiens wallerana Hook.f. grown in recirculating subirrigation and found that rates could be reduced to $4 \mathrm{~mm} \mathrm{~N}$. Klock-Moore and Broschat (1999) grew Petunia $\times$ hybrida Hort. Vilm.-Andr. in subirrigation or topwatering systems with slow-release fertilizer. Subirrigated petunias fertilized with Osmocote $14 \mathrm{~N}-6.2 \mathrm{P}-11.6 \mathrm{~K}$ at a rate of $2.5 \mathrm{~kg} \cdot \mathrm{m}^{-3}$ had a shoot dry weight similar to top-watered petunias fertilized with $7.5 \mathrm{~kg} \cdot \mathrm{m}^{-3}$, suggesting that fertilizer rates can be reduced for petunias grown with subirrigation. Yelanich and Biernbaum (1993) grew Euphorbia pulcherrima Willd. ex Klotzsch with various $\mathrm{N}$ fertilizer rates and leaching fractions with top-watering. They demonstrated that poinsettias required less fertilizer (1996) varied N levels of greenhouse plants in when grown with smaller leaching fractions or with no leaching, as occurs in subirrigation, and were similar to or larger than plants grown at higher fertilizer concentrations or leaching fractions. Subirrigation studies have focused mainly on nitrogen nutrition and little is known about other essential elements.

The objectives of this study were to use recirculating subirrigation as a model zero-leach system to 1) determine optimum $\mathrm{K}$ concentrations for New Guinea impatiens, vinca, and petunia with zero-leach recirculating subirrigation and 2) compare $\mathrm{K}$ balance of vinca grown with zero-leach recirculating subirrigation versus top-watering with a moderate leaching fraction.

\section{Materials and Methods}

All experiments were conducted in a glass greenhouse at Texas A\&M University, College Station. The growing medium was peat-perlite mix Sunshine \#2 (Sun Gro Horticulture, Bellevue, Wash.), which contained lime (initial $\mathrm{pH}$ of 5.6) but no added nutrients, and was amended with the label rate of $1.059 \mathrm{~kg} \cdot \mathrm{m}^{-3}$ Micromax trace element mix (Scotts Sierra, Marysville, Ohio). Subirrigation trays were arranged on two greenhouse benches in each experiment. Each subirrigation tray was connected to individual reservoir tanks of fertilizer solution. Submersible pumps in the tanks were manually controlled to flood the trays to 1 -inch depth. Trays required $<5 \mathrm{~min}$ to fill and were maintained flooded for 10 to $15 \mathrm{~min}$, allowing enough time for the medium to become saturated. Trays required $<5$ min to drain.

Weekly measurements included plant height and leaf number. Destructive measurements included fresh weight, dry weight, and leaf area. Leaf area was determined using leaves plus petioles of all leaves $>0.5 \mathrm{~cm}$ in length using a leaf area meter (model AM82 leaf area meter; Delta-T Devices Ltd., Cambridge, U.K.). For analysis of the growing medium, the medium was removed from the pot and cut horizontally into three equal top, middle, and bottom layers. After drying, a sample from each layer was extracted by the 1:2 dilution method (Nelson, 1996) and measured for $\mathrm{pH}, \mathrm{EC}$, and K concentration. The $\mathrm{pH}$ was measured by using a twin $\mathrm{pH}$ meter (Spectrum Technologies, Inc., Plainfield, Ill.), the EC using a twin conductivity meter (B-173; Horiba Instruments, Inc., Irvine, Calif.), and the K concentration using a Cardy compact ion meter (Horiba Instruments, Inc., Irvine, Calif.).

Experiment 1. New Guinea impatiens 'Ovation Salmon Pink Swirl' (Oglevee, Ltd., Connesville, Pa.) from 288 plug trays were transplanted into 9.5 -cm-diameter plastic pots. The experiment began on 11 Jan. 2000 and ended on 14 Mar. 2000. Average daily noon temperature was $26.7^{\circ} \mathrm{C}$, the relative humidity $(\mathrm{RH})$ was $48 \%$ and $P P F$ (photosynthetic photon flux) was $400 \mu \mathrm{mol} \cdot \mathrm{m}^{-2} \cdot \mathrm{s}^{-1}$ (Quantum Light Data Logger, Spectrum Technologies, Plainfield, Ill.). The experiment was a single factor design of nine $\mathrm{K}$ concentrations to yield subirrigation solutions of $0,0.5,1.0,1.5,2.0$, 3.0, 6.0, 9.0, and $12.0 \mathrm{~mm} \mathrm{~K}$ supplied by $\mathrm{K}_{2} \mathrm{SO}_{4}$. 
Table 1. Effects of varying K concentrations on growth of new guinea impatiens 'Ovation Salmon Pink Swirl' grown in recirculating subirrigation at final harvest (day 78). ${ }^{2}$

\begin{tabular}{|c|c|c|c|c|}
\hline $\begin{array}{l}\text { Concn } \\
(\mathrm{mm} \mathrm{K})\end{array}$ & $\begin{array}{l}\mathrm{Ht} \\
(\mathrm{cm})\end{array}$ & $\begin{array}{l}\text { Shoot } \\
\text { dry wt } \\
\text { (g) }\end{array}$ & $\begin{array}{l}\text { Total } \\
\text { leaf } \\
\text { area } \\
\left(\mathrm{cm}^{2}\right)\end{array}$ & $\begin{array}{c}\text { Total } \\
\text { leaves } \\
\text { (no.) }\end{array}$ \\
\hline$\overline{0}$ & $9.6 \mathrm{~d}^{\mathrm{y}}$ & $4.8 \mathrm{~d}$ & $660 \mathrm{e}$ & $133 \mathrm{f}$ \\
\hline 0.5 & $12.8 \mathrm{c}$ & $12.5 \mathrm{bc}$ & $2174 \mathrm{bcd}$ & $229 \mathrm{cde}$ \\
\hline 1 & $14.1 \mathrm{abc}$ & $15.8 \mathrm{ab}$ & $2967 \mathrm{a}$ & $340 \mathrm{a}$ \\
\hline 1.5 & $14.6 \mathrm{ab}$ & $17.1 \mathrm{a}$ & $2907 \mathrm{a}$ & $325 a b$ \\
\hline 2 & $13.4 \mathrm{bc}$ & $14.0 \mathrm{abc}$ & $2508 \mathrm{abc}$ & $273 \mathrm{bdc}$ \\
\hline 3 & $14.2 \mathrm{abc}$ & $15.5 \mathrm{ab}$ & $2596 \mathrm{abc}$ & $274 \mathrm{bc}$ \\
\hline 6 & $15.2 \mathrm{a}$ & $16.5 \mathrm{a}$ & $2927 \mathrm{ab}$ & 254 cde \\
\hline 9 & $14.0 \mathrm{abc}$ & $12.7 \mathrm{bc}$ & $2011 \mathrm{~cd}$ & $215 \mathrm{~cd}$ \\
\hline 12 & $13.6 \mathrm{abc}$ & $12.7 \mathrm{bc}$ & $1875 \mathrm{~d}$ & $212 \mathrm{e}$ \\
\hline $0.5 / 1 \mathrm{~K} / \mathrm{S}$ & $12.7 \mathrm{c}$ & $11.6 \mathrm{c}$ & $1918 d$ & $214 \mathrm{de}$ \\
\hline Significance & $* * *$ & $* * *$ & $* * *$ & $* * *$ \\
\hline
\end{tabular}

${ }^{2}$ Data represents means of 10 plants.

${ }^{y}$ Means within columns with the same letter are not significantly different at $P<0.05$ as determined by LSD. **** Significant at $P<0.001$, by ANOVA.

Ten plants were used per treatment. All treatments contained $8.0 \mathrm{~mm} \mathrm{~N}$ and $1.5 \mathrm{~mm} \mathrm{P}$ from technical grade $\left(\mathrm{NH}_{4}\right)_{2} \mathrm{HPO}_{4},\left(\mathrm{NH}_{4}\right) \mathrm{H}_{2} \mathrm{PO}_{4}$, and $\mathrm{NH}_{4} \mathrm{NO}_{3}$. A tenth treatment contained $0.5 \mathrm{~mm} \mathrm{~K}$ and $1.0 \mathrm{~mm}$ S, plus $8.0 \mathrm{~mm} \mathrm{~N}$ and $1.5 \mathrm{~mm} P$ from $\left(\mathrm{NH}_{4}\right)_{2} \mathrm{SO}_{4}, \mathrm{KNO}_{3},\left(\mathrm{NH}_{4}\right)_{2} \mathrm{HPO}_{4},\left(\mathrm{NH}_{4}\right) \mathrm{H}_{2} \mathrm{PO}_{4}$, and $\mathrm{NH}_{4} \mathrm{NO}_{3}$. All solutions were prepared with reverse osmosis purified water.

Experiment 2. The second experiment's objective was to compare the optimum $\mathrm{K}$ concentrations established in Expt. 1 for several greenhouse plants grown in subirrigation. Plugs of Impatiens $\times$ hawkeri Bull. 'Cameo'(Oglevee, Ltd., Connesville, Pa.), Impatiens $\times$ hawkeri Bull. 'Illusion' (Oglevee, Ltd.), Catharanthus roseus (L.) Don. 'Pacifica Apricot' (Colorspot, Huntsville, Tex.), and Petunia $\times$ hybrida Hort. Vilm.-Andr. 'Trailing Wave Misty Lilac' (Colorspot, Huntsville, Texas) from 288 plug trays were transplanted into 9.5 -cm-diameter plastic pots. The experiment began on 11 Apr. 2000 and was terminated on 30 May 2000. Average noon temperature was $29.7{ }^{\circ} \mathrm{C}$, RH was $59 \%$ and $P P F$ was $545 \mu \mathrm{mol} \cdot \mathrm{m}^{-2} \cdot \mathrm{s}^{-1}$. The experimental design was a completely randomized $4 \times 6$ factorial, with four plant species and six fertilizer concentrations. The experiment was a single factor design of six $\mathrm{K}$ concentrations to yield subirrigation solutions of $0,2,4,8,16$, and $24 \mathrm{~mm} \mathrm{~K}$ supplied by $\mathrm{K}_{2} \mathrm{SO}_{4}$. Five plants were used per treatment.

Experiment 3. This experiment was a comparative study of optimum K concentrations and $\mathrm{K}$ balance in subirrigation versus a top-watered system. Plugs of vinca and Catharanthus roseus Hort.Vilm.-Andr. 'Pacifica Red' (Colorspot, Huntsville, Tex.) from 288 plug trays were transplanted into $9.5-\mathrm{cm}$-diameter plastic pots. The experiment began on 28 Sept. 2000 and was terminated on 14 Dec. 2000 . Average daily noon temperature was $24.6{ }^{\circ} \mathrm{C}$, RH was $67 \%$ and $P P F$ was $245.5 \mu \mathrm{mol} \cdot \mathrm{m}^{-2} \cdot \mathrm{s}^{-1}$. The treatments consisted of the same $\mathrm{K}$ concentrations used in Expt. 2. Five plants were used per treatment. In the subirrigation treatment, subirrigation was as in previous experiments. For top-watered treatment, plants were irrigated by hand with the respective treatments to yield a leaching fraction of 0.15 to 0.35 for all containers. Leachate was collected and measured for each container at each irrigation.

The K balance was determined for the $2 \mathrm{~mm}$ $\mathrm{K}$ and $16 \mathrm{mM} \mathrm{K}$ treatments in both subirrigated

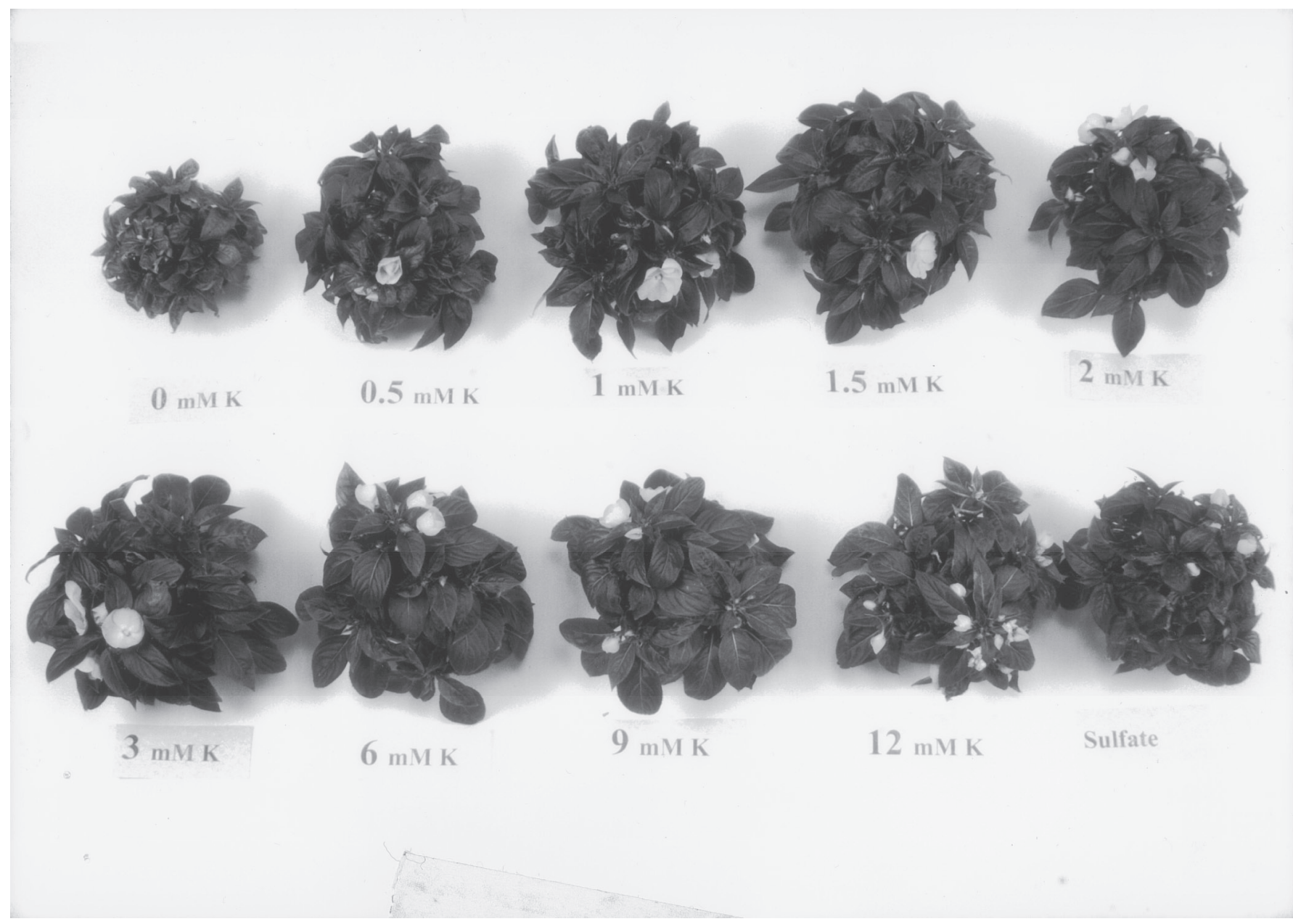

Fig. 1. Representative new guinea impatiens 'Ovation Salmon Pink Swirl' grown with varying K concentrations in recirculating subirrigation at final harvest (day 78). 
Table 2. Effect of varying K concentrations on shoot dry weight of new guinea impatiens 'Cameo', New Guinea impatiens 'Illusion', vinca 'Pacifica Apricot', and petunia 'Trailing Wave Misty Lilac' grown in recirculating subirrigation at final harvest (day 49).

\begin{tabular}{|c|c|c|c|c|}
\hline \multirow[b]{2}{*}{$\begin{array}{l}\text { Concentration } \\
(\mathrm{mm} \mathrm{K})\end{array}$} & \multicolumn{4}{|c|}{ Shoot dry wt $(\mathrm{g})^{\mathrm{z}}$} \\
\hline & $\begin{array}{l}\text { New guinea } \\
\text { impatiens } \\
\text { 'Cameo' }\end{array}$ & $\begin{array}{l}\text { New guinea } \\
\text { impatiens } \\
\text { 'Illusion' }\end{array}$ & $\begin{array}{c}\text { Vinca } \\
\text { 'Pacifica } \\
\text { Apricot' }\end{array}$ & $\begin{array}{c}\text { Petunia } \\
\text { 'Trailing Wave } \\
\text { Misty Lilac' }\end{array}$ \\
\hline$\overline{0}$ & $2.2 \mathrm{e}^{y}$ & $3.3 \mathrm{~d}$ & $3.4 \mathrm{~d}$ & $3.2 \mathrm{c}$ \\
\hline 2 & $11.5 \mathrm{a}$ & $11.9 \mathrm{a}$ & $8.7 \mathrm{a}$ & $13.2 \mathrm{ab}$ \\
\hline 4 & $10.4 \mathrm{~b}$ & $10.3 \mathrm{~b}$ & $8.7 \mathrm{a}$ & $14.3 \mathrm{a}$ \\
\hline 8 & $8.2 \mathrm{c}$ & $8.9 \mathrm{~b}$ & $9.0 \mathrm{a}$ & $14.5 \mathrm{a}$ \\
\hline 16 & $7.4 \mathrm{~cd}$ & $7.0 \mathrm{c}$ & $7.3 \mathrm{~b}$ & $13.4 \mathrm{ab}$ \\
\hline 24 & $6.6 \mathrm{~d}$ & $6.1 \mathrm{c}$ & $6.4 \mathrm{c}$ & $12.3 \mathrm{~b}$ \\
\hline Significance & $* * *$ & $* * *$ & $* * *$ & $* * *$ \\
\hline
\end{tabular}

${ }^{2}$ Data represents means of 5 plants.

${ }^{\mathrm{y}}$ Means within columns with the same letter are not significantly different at $P<0.05$ as determined by LSD. **** Significant at $P<0.001$, by ANOVA.

Table 3. Effects of varying $\mathrm{K}$ concentrations on growth parameters of vinca 'Pacifica Red' grown in recirculating subirrigation and with top-watering at final harvest (day 78).

\begin{tabular}{|c|c|c|c|}
\hline $\begin{array}{l}\text { Concn } \\
(\mathrm{mm} \mathrm{K})\end{array}$ & $\begin{array}{c}\mathrm{Ht} \\
(\mathrm{cm})\end{array}$ & $\begin{array}{l}\text { Shoot } \\
\text { fresh } \\
\text { wt }(g)\end{array}$ & $\begin{array}{c}\text { Total } \\
\text { leaf } \\
\text { area } \\
\left(\mathrm{cm}^{2}\right)\end{array}$ \\
\hline \multicolumn{4}{|l|}{ Subirrigation $^{2}$} \\
\hline 0 & $19.8 c^{y}$ & $43.6 \mathrm{~d}^{\mathrm{y}}$ & $1311 c^{y}$ \\
\hline 2 & $23.7 \mathrm{a}$ & $66.9 \mathrm{a}$ & 1953 a \\
\hline 4 & $21.9 \mathrm{~b}$ & $60.7 \mathrm{~b}$ & $1864 a b$ \\
\hline 8 & $21.5 \mathrm{bc}$ & $59.9 \mathrm{~b}$ & $1667 \mathrm{~b}$ \\
\hline 16 & $20.7 \mathrm{bc}$ & $56.3 \mathrm{~b}$ & $1647 \mathrm{~b}$ \\
\hline 24 & $20.7 \mathrm{bc}$ & $50.1 \mathrm{c}$ & $1393 \mathrm{c}$ \\
\hline \multicolumn{4}{|l|}{ Top-water ${ }^{z}$} \\
\hline 0 & $16.1 \mathrm{c}$ & $25.1 \mathrm{~d}$ & $754 \mathrm{~d}$ \\
\hline 2 & $22.0 \mathrm{ab}$ & $49.0 \mathrm{bc}$ & $1390 \mathrm{bc}$ \\
\hline 4 & $22.6 \mathrm{a}$ & $63.0 \mathrm{a}$ & 1928 a \\
\hline 8 & $20.7 \mathrm{ab}$ & $51.1 \mathrm{~b}$ & $1480 \mathrm{bc}$ \\
\hline 16 & $19.7 \mathrm{~b}$ & $53.5 \mathrm{~b}$ & $1552 \mathrm{~b}$ \\
\hline 24 & $22.0 \mathrm{ab}$ & $43.1 \mathrm{c}$ & $1245 \mathrm{c}$ \\
\hline \multicolumn{4}{|l|}{ Significance } \\
\hline Rate & $* * *$ & $* * *$ & $* * *$ \\
\hline Irrigation & $* * *$ & $* * *$ & $* * *$ \\
\hline \multicolumn{2}{|c|}{ Rate $\times$ irrigation $* * *$} & $* * *$ & $* * *$ \\
\hline
\end{tabular}

${ }^{2}$ Data represents means of five plants.

${ }^{\mathrm{y}}$ Means within columns with each irrigation method with the same letter are not significantly different at $P<0.05$ as determined by LSD.

*** Significant at $P<0.001$, by ANOVA.

and top-watered treatments. Five plants were harvested for each treatment. The $\mathrm{K}$ content was determined in plant tops (shoots + leaves + flowers), the growing medium (top, middle and, bottom layers), and leachate in the top-watering treatments. The $\mathrm{K}$ content of the subirrigation solution was monitored periodically, and the $\mathrm{K}$ concentration did not change over the course of the experiment. The procedure for determining $\mathrm{K}$ was a nitric acid wet digest procedure using a block digester. A 0.25 -g sample of ground plant dry matter was added to $5 \mathrm{~mL}$ of trace metal grade nitric acid and placed on a digestion block set at $120^{\circ} \mathrm{C}$ for $4 \mathrm{~h}$. The sample was allowed to cool and then $15 \mathrm{~mL}$ of deionized water was added. Potassium was analyzed by ICP (Texas A\&M Soil Testing Lab).

\section{Results and Discussion}

Experiment 1. Growth of New Guinea impatiens 'Ovation Salmon Pink Swirl' increased as $\mathrm{K}$ concentration increased to $1 \mathrm{~mm}$, remained relatively constant between 1 to $6 \mathrm{~mm}$, and

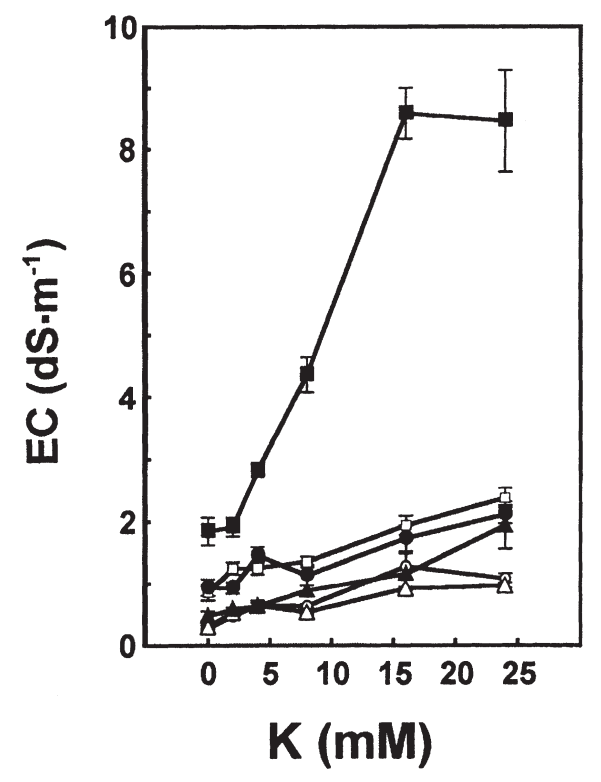

Fig. 2. Growing medium EC of vinca 'Pacifica Red' at final harvest (day 78) grown with varying $\mathrm{K}$ concentrations in either recirculating subirrigation or top-watering. Growing medium was removed from the pot and cut into three equal horizontal layers; top, middle, and bottom. The recommended EC is $1.2 \mathrm{dS} \cdot \mathrm{m}^{-1}$ based on the $1: 2$ dilution method (Lang, 1996). Bars represent standard error of the mean; $n=5$. Subirrigation: top layer $=\boldsymbol{\square}$, middle layer $=\boldsymbol{0}$, bottom layer $=$ $\boldsymbol{\Delta}$. Top-watering: top layer $=\square$, middle layer $=$ $\bigcirc$, bottom layer $=\Delta$.

then decreased at $9 \mathrm{~mm}$ and above (Table 1, Fig. 1). Thus, adequate growth was maintained over a broad range of $\mathrm{K}$ concentrations. The 0 $\mathrm{mm} \mathrm{K}$ control plants were stunted, had fewer flowers, exhibited leaf abscission, leaf curling, and chlorosis, suggesting $\mathrm{K}$ deficiency. In the highest $\mathrm{K}$ treatment, $12 \mathrm{~mm} \mathrm{~K}$, the leaves had rippled leaf surfaces and cupping of leaf margins, especially on the younger leaves; this suggests K toxicity or a general toxicity to high soluble salts (Hartley, 1995). Overall, the lowest $\mathrm{K}$ concentration that yielded the maximum growth were $1 \mathrm{~mm} \mathrm{~K}$. This is half the fertilizer concentration compared to that recommended for top-watered plants, usually around 2 to 3 mм K (Hartley, 1995).

The low K/high S treatment had a K concentration equal to the $0.5 \mathrm{~mm} \mathrm{~K}$ treatment and an $\mathrm{S}$ concentration equal to the $2 \mathrm{~mm} \mathrm{~K}$ treatment.
The absolute size of the plants in the low K/high $\mathrm{S}$ treatment was similar to the plants in the 0.5 mм K treatment rather than those in the $2.0 \mathrm{~mm} \mathrm{~K}$ treatment(Table 1). This indicates that the growth response observed was due to the $\mathrm{K}$ and not the sulfate carrier in the various treatments.

The EC was measured in top, middle, and bottom layers for each treatment (data not shown). The EC of the middle and bottom layers remained below the recommended limit of 1.2 $\mathrm{dS} \cdot \mathrm{m}^{-1}$ (Lang, 1996) in all treatments, except the 9 and $12 \mathrm{~mm} \mathrm{~K}$ treatments, which reached 1.5 and $1.9 \mathrm{dS} \cdot \mathrm{m}^{-1}$, respectively. The EC of the top layer exceeded the limit of $1.2 \mathrm{dS} \cdot \mathrm{m}^{-1}$ in treatments of $0.5 \mathrm{~mm} \mathrm{~K}$ and above, and reached $11 \mathrm{dS} \cdot \mathrm{m}^{-1}$ in the $12 \mathrm{~mm} \mathrm{~K}$ treatment. However, plants survived even with these high EC levels in the top layer, which is probably due to the fact that roots are concentrated in middle and bottom layers of the media in subirrigated plants (Kent and Reed, 1996). Thus, in subirrigation there is an upward leaching of soluble salts out of the effective root zone.

Potassium concentrations in the growing medium (data not shown) followed the same trend as EC. Potassium concentration was similar in middle and bottom layers, but was three to five times higher in the top layer. As with soluble salts, there is an upward leaching of the $\mathrm{K}$ out of the effective root zone.

The initial $\mathrm{pH}$ of the growing medium was 5.6. There was a significant effect of rate and layer on final growing medium $\mathrm{pH}$. Final $\mathrm{pH}$ decreased more as rate increased, and from top to the bottom of the container (data not shown). The lowest final $\mathrm{pH}$ recorded was about 1 unit lower than the initial $\mathrm{pH}$. The decreased $\mathrm{pH}$ values observed were probably due to the higher ammonium versus nitrate concentration present in all solutions (Bailey, 1996), and reflect regions of concentration of salts.

Experiment 2. Based upon final shoot dry weight (Table 2), shoot fresh weight, leaf number and plant height (data not shown), with subirrigation New Guinea impatiens 'Cameo' and 'Illusion' exhibited maximum growth at $2 \mathrm{~mm} \mathrm{~K}$, vinca 'Pacifica Apricot' at 2 to $8 \mathrm{~mm}$ $\mathrm{K}$, and petunia 'Trailing Wave Misty Lilac' at 2 to $16 \mathrm{~mm} \mathrm{~K}$.

Growing medium extract results were similar to the findings in Expt. 1. Growing medium $\mathrm{EC}$ increased with increasing $\mathrm{K}$ levels (data not shown). The top layer had a very high EC, ranging from 8 to $12 \mathrm{dS} \cdot \mathrm{m}^{-1}$ in the higher (16 and $24 \mathrm{~mm}$ ) $\mathrm{K}$ fertilizer treatments, while the bottom and middle layers were in an acceptable $\mathrm{EC}$ range for all treatments. Growing medium $\mathrm{K}$ in the top layer was twice the $\mathrm{K}$ level in the middle and bottom layers (data not shown). As in Expt. 1, growing medium $\mathrm{pH}$ decreased slightly through the course of the experiment (date not shown).

Experiment 3. Based on a variety of growth parameters, vinca 'Pacifica Red' consistently exhibited maximum growth at $2 \mathrm{~mm} \mathrm{~K}$ in recirculating subirrigation and at $4 \mathrm{~mm} \mathrm{~K}$ with top-watering (Table 3). This is similar to other studies which demonstrate that plants grown in subirrigation exhibit adequate growth at about half the fertilizer concentration of plants grown with top watering (Fischer, 2000). 


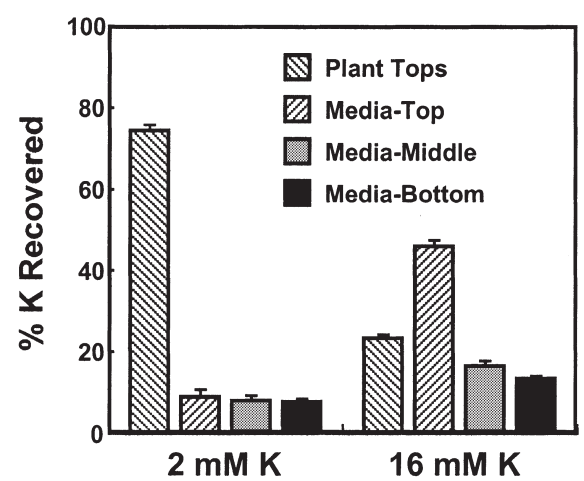

Fig. 3. Total percent $K$ recovered in plant tops and growing media plus roots in the top, middle and bottom layers in subirrigated vinca 'Pacifica Red' plants at final harvest (day 78). Bars represent standard error of the mean; $n=5$.

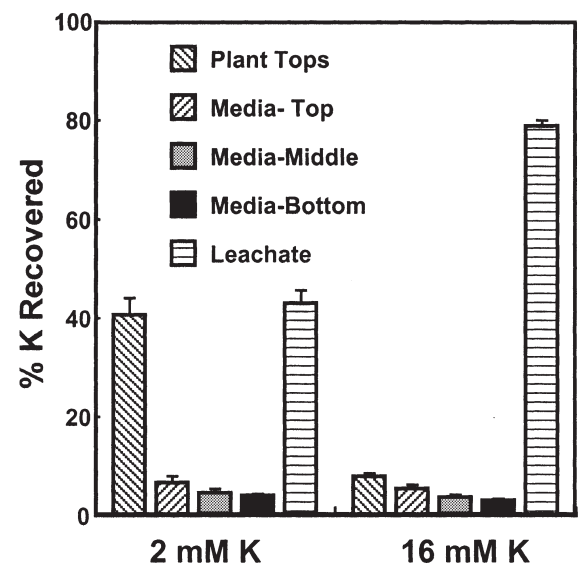

Fig. 4. Total percent $\mathrm{K}$ recovered in plant tops, growing media plus roots in the top, middle and bottom layers, and leachate in top-watered vinca 'Pacifica Red' plants at final harvest (day 78). Bars represent standard error of the mean; $\mathrm{n}=5$.

Growing media $\mathrm{pH}$ was similar for plants grown in recirculating subirrigation or with top-watering. Both irrigation methods had a slightly lower growing medium $\mathrm{pH}$ at final harvest (data not shown). Growing media EC at final harvest differed by irrigation method
(Fig. 2). In the top-water treatment, the only growing medium layers that were above the recommended EC level of $1.2 \mathrm{dS} \cdot \mathrm{m}^{-1}$ (Lang, 1996) were the top layer of the 8,16 , and $24 \mathrm{~mm}$ $\mathrm{K}$ treatments. With subirrigation, the growing media EC in the top layer was above $1.2 \mathrm{dS} \cdot \mathrm{m}^{-1}$ in all treatments, reaching a maximum of 8.5 $\mathrm{dS} \cdot \mathrm{m}^{-1}$ in the 16 and $24 \mathrm{~mm} \mathrm{~K}$ treatment. This is about 7 times the recommended level. Thus, salt stratification in the top layer was documented in both irrigation methods, but was much more dramatic in recirculating subirrigation.

With subirrigation, the Kbalance of the $2 \mathrm{~mm}$ K treatment was very efficient, with over $70 \%$ of applied $\mathrm{K}$ recovered in plant tops (Fig. 3). The $16 \mathrm{~mm} \mathrm{~K}$ treatment was very inefficient, with only $20 \%$ of applied $\mathrm{K}$ recovered in the plant tops. The $16 \mathrm{~mm} \mathrm{~K}$ treatment had the greatest amount of $\mathrm{K}$ recovered in the top layer of the media, where there were few roots, thus much of the $\mathrm{K}$ was not usable by the plant.

With top-watering, only $40 \%$ of applied $\mathrm{K}$ was recovered in the plant tops in the $2 \mathrm{~mm}$ treatment (Fig. 4). The $16 \mathrm{~mm} \mathrm{~K}$ treatment was very inefficient, with $<10 \%$ recovery of $\mathrm{K}$ in plant tops. Inefficiency of top-watering treatments was due to $40 \%$ to $80 \%$ of K lost due to leaching.

Plants in subirrigation treatments were about twice as efficient in recovering applied $\mathrm{K}$ in plant tops (Fig. 3) compared to the top-watered treatments (Fig. 4). Losses due to leaching in the top-watered treatments accounted for the inefficiency. This dramatically emphasizes that subirrigation is more efficient in fertilizer usage.

In conclusion, like other nutrients studied in subirrigation, the $\mathrm{K}$ fertilizer concentration supplied can be reduced by nearly half and yield adequate growth compared to that traditionally recommended for top-watered plants. In addition, the $\mathrm{K}$ is more efficiently used in subirrigation and no K is lost to the environment that could end up in groundwater.

\section{Literature Cited}

Bailey, D.A. 1996. Alkalinity, pH and acidification, p. 69-92. In: D.W. Reed (ed.). Water, media and nutrition for greenhouse crops. Ball Publ. Batavia, Ill.

Elliott, G. 1992. A pulsed subirrigation system for small plots. HortScience 27:71-72.

Fischer, R. 2000. Flood floor FAQs. Grower Talks 63(12):42-48.

Hartley, D. 1995. Feeding and watering, p. 31-37. In: W. Banner and M. Klopmeyer (eds.). New Guinea impatiens: A Ball guide. Ball Publ., Batavia, Ill.

James, E. and M. van Iersel. 2001. Fertilizerconcentrations affect growth and flowering of subirrigated petunias and begonias. HortScience 36:40-44.

Kent, M. and D.W. Reed. 1996. Nitrogen nutrition of New Guinea impatiens 'Barbados' and Spathiphyllum 'Petite' in a subirrigation system. J. Amer. Soc. Hort. Sci. 121:816-819.

Klock-Moore, K.A. and T.K. Broschat. 1999. Differences in bedding plant growth and nitrate loss with a controlled-release fertilizer and two irrigation systems. HortTechnology 9:206-209.

Lang, H.J. 1996. Growing media testing and interpretation, p. 123-140. In: D.W. Reed (ed.). Water, media and nutrition for greenhouse crops. Ball Publ., Batavia, Ill.

Molitor, H. 1990. The European perspective with emphasis on subirrigation and recirculation of water and nutrients. Acta Hort. 272:165-173.

Nelson, P. 1996. Macronutrient fertilizer programs, p. 141-155. In: D.W. Reed (ed.). Water, media and nutrition for greenhouse crops. Ball Publ., Batavia, Ill.

Reed. D.W. 1996. Closed production systems for containerized crops: Recirculating subirrigation and zero-leach systems. In: D.W. Reed (ed.). Water, media and nutrition for greenhouse crops. Ball Publ., Batavia, Ill.

Skimina, C.A. 1996. Total nursery recycling systems, p. 247-262. In: D.W. Reed (ed.). Water, media and nutrition for greenhouse crops. Ball Publ., Batavia, Ill.

Todd, N. and D. W. Reed. 1998. Characterizing salinity limits of new guinea impatiens in recirculating subirrigation. J. Amer. Soc. Hort. Sci. 123:156-160

Whipker, B.E., S. Dasoju, M.S. Dosmann, and J.K. Iles. 1999. Effect of fertilizer concentration on growth of double impatiens. HortTechnology 9:425-428.

Yelanich, M.V. and J.A. Biernbaum. 1993. Rootmedium nutrient concentration and growth of poinsettia at three fertilizer concentrations and four leaching fractions. J. Amer. Soc. Hort. Sci. 118:771-776. 